\section{ADDITIONS TO THE BUTTERFLIES OF GOVERNMENT COLLEGE CAMPUS, KOZHIKODE DISTRICT, KERALA}

\author{
Vinayan P. Nair \\ P.G.. \& Research Department of Zoology, St. Joseph College \\ Devagiri, Kozhikode, Kerala 637008, India. \\ Email:vinayanpnair@yahoo.co.in
}

Seventy-three species of butterflies were reported from the Government College Campus, Madappally, Vatakara, Kozhikode District, Kerala (Nair, 2002). Further surveys and collections indicated the presence of 24 more species of butterflies in and around the campus. Some of the butterflies which resisted capture during the previous survey were collected during this survey. The survey was made during 2001-2002.

This raises the total number of butterfly species of the campus to 96 . During this survey 14 species of skippers, four species of blues and five species of nymphalids were recorded. Thus totally from the campus maximum species of butterflies were observed in the family Nymphalidae (37 species) followed by Hesperiidae (22 species). The butterflies were identified and verified following Wynter-Blyth (1957), Evans (1932) and Kunte (2000). A systematic list of all the butterflies recorded from the Government College Campus, Madappally is given in Table 1. Nomenclature and classification of butterflies is after Gaonkar (1996).

\section{Acknowledgements}

I am grateful to Dr. C. Radhakrishnan (Joint Director, ZSI, WGRS, Kozhikode), Dr. P.M. Sureshan (ZSI, Pune) and Md. Jafer Palot (ZSI, Kozhikode) for constant encouragement and facilities. I thank Prof. A.R. Thomas, Head, Department of Zoology, St. Joseph's College, Devagiri for facilities. I am also grateful to Prof. P.V. Balakrishnan (H.O.D. of Zoology, Government College, Madappally, Vatakara) for this help in this study.

\section{References}

Evans, W.H (1932). The Identification of Indian Butterflies. 1985 Reprint edition. International Book Distributors, Dehradun.

Gaonkar, H. (1996). Butterflies of the Western Ghats, India (including Sri Lanka): A biodiversity threatened mountain system. Report to the Centre for Ecological Sciences (Unpublished).

Kunte, K. (2000). India - A Lifescape: Butterflies of Peninsular India. Universities Press, Hyderabad.
Nair, V.P. (2002). Butterflies of the Government College Campus, Madappally, Kozhikode District, Kerala. Zoos Print Journal 17(10): 911-912.

Wynter-Blyth, M.A. (1957). Butterflies of the Indian Region. Bombay Natural History Society, Bombay, 523pp.+72 pls.

Table 1. Additions to the butterflies of Government College Campus, Madappally, Kozhikode District, Kerala

\begin{tabular}{ll}
\hline Scientific name & Common name \\
\hline Nymphalidae & \\
\hline Melanitis zitenius (Herbst) & Great Evening Brown \\
Ypthima asterope (Klug) & Common Three-ring \\
Acraea violae (Fabricius) & Tawny Coster \\
Phalanta phalanta (Drury) & Common Leopard \\
Hypolimnas missippus (Linnaeus) & DanaidEggfly \\
Parantica aglea (Stoll) & Glassy Blue Tiger
\end{tabular}

Lycaenidae

Actolepis puspa (Horsefield)

Jamides celeno (Cramer)

Spindasis vulcanus (Fabricius)

Rapala manea (Hewitson)

Common Hedge Blue

Common Cerulean

Common Silverline

Slate Flash

\section{Hesperiidae}

Hasora chromus (Cramer)

Celaenorrhinus leucocera (Kollar)

Pseudocoladenia dan (Fabricius)

Coladenis indrani (Moore)

Sarangesa dasahara (Moore)

Spialia galba (Fabricius)

Aeromachus dubius (Elwes\&Edwards)

Ampittia dioscorides (Fabricius)

Psolos fuligo (Mabille)

Matapa aria (Moore)

Taractrocera maevius (Fabricius)

Taractrocera ceramas (Hewitson)

Oriens goloides (Moore)

Potanthus palnia? (Evans)
Common Banded Awl

Common Spotted Flat

Fulvous Pied Flat

Tricolor Pied Flat Common Small Flat

Indian Grizzled Skipper

Dingy Scrub Hopper

Bush Hopper

Coon

Common Red-eye

Common Grass Dart

Tamil Grass Dart

Indian Dartlet

Palni Dart 